\title{
WOMEN IN APHRAHAT: SOME OBSERVATIONS
}

\author{
ADAM LEHTO \\ KITCHENER, ONTARIO \\ CANADA
}

\begin{abstract}
Certain passages in Aphrahat's Demonstrations exhibit misogynist language, since women are portrayed as instruments of Satan and are blamed for the evil state of the world. A consideration of other aspects of Aphrabat's thought allows for a more nuanced view of Aphrabat's attitudes toward women. These other aspects include: i) the role of Mary in salvation history; ii) the eschatogical context of Aphrahat's asceticism; iii) the fact that men are demonized more than women in the Demonstrations; iv) the fact that Aphrahat makes unambiguously positive statements about women.
\end{abstract}

[1] The fourth century writer known to us as Aphrahat ${ }^{1}$ has the distinction of being the first clear personality, among authors, that

${ }^{1}$ The name "Aphrahat," which almost certainly means 'wise man' in Persian, appears only in the $10^{\text {th }}$ century, whereas the more cumbersome title "Persian Sage" is quite early, showing up in all the earliest manuscripts ( $5^{\text {th }}$ and $6^{\text {th }}$ centuries). See Marie-Joseph Pierre's introduction to Aphrahat for a full discussion of the possible identity of the author of the Demonstrations (Aphraate Le Sage Persan: Les Exposés, vol. 1 (Paris: Les Éditions du Cerf, 1988) 33-41). 
we know of in the Syriac tradition. ${ }^{2}$ The title of his single known work, which was written in three stages between 336 and 345 C.E., is derived from the initial word ('demonstration') found in each of the titles that Aphrahat gives to the 23 separate pieces included in the collection. What is being 'demonstrated' is the congruity of Aphrahat's arguments with the scriptures: a prominent characteristic of the work is the sheer number of biblical citations and allusions. His theology predates the influence of Greek philosophical and mystical theology on the Syriac tradition, an influence which begins in the $5^{\text {th }}$ century and is evident in writers such as Philoxenus (d. 523).

Another prominent feature of the Demonstrations is their concern about the threat of Judaism to the Christian community. In addition to various isolated passages throughout, nine of the twenty-three demonstrations focus explicitly on this threat, seeking to show that the Jews have been rejected and that the Church has become God's chosen people, drawn from all the peoples of the world. However, the topic of the present paper has little to do with this aspect of Aphrahat's thought. Of the few extant works earlier than Aphrahat of Syrian provenance, none but the Didascalia exhibit a preoccupation with Judaism.

This is not the case with another major feature of Aphrahat's work: its ascetic orientation. As will be noted below (see paragraph 6), the rejection of marriage has deep roots in Syriac Christianity. And even though writers such as Aphrahat and his slightly younger contemporary Ephrem affirm the legitimacy of marriage as a form of Christian living, they themselves make it quite clear, as do most early Syriac sources, that their preference is for celibacy. Aphrahat's form of asceticism, shared with all of the so-called 'covenanters', ${ }^{3}$

${ }^{2}$ The clearest and most succinct disscussion of early Syriac sources is in Robert Murray, "The Characteristics of the Earliest Syriac Christianity," in Nina Garsoian et. al. (ed.), East of Byzantium: Syria and Armenia in the Formative Period, (Washington D.C.: Dumbarton Oaks, 1982) 3-6. As Murray points out, Bardaisan is "the first clear personality in Syriac literature," but we have nothing from his own hand.

${ }^{3}$ I use the term suggested by George Nedungatt, "The Covenanters of the Early Syriac-Speaking Church," OCP 39 (1973): 203. It has become clear that the word qyâmâ had a range of meanings in the early Syriac church. In a recent discussion, Sidney Griffith attributes this range of meaning to the polyvalency of Semitic roots (Sidney H. Griffith, 
predates the appearance of cenobitical monasticism, which was influenced by Egyptian models, later in the $4^{\text {th }}$ century in Syria. ${ }^{4}$ There is no need here for a detailed description of the shape of the ascetic life as represented by Aphrahat. ${ }^{5}$ It will be sufficient to note that in demonstration six, he addresses female ascetics directly, which indicates that the community he felt responsible for was not exclusively male.

No reader of Aphrahat's sixth demonstration ("On Covenanters") can fail to be struck by certain passages which

"Asceticism in the Church of Syria: The Hermeneutics of Early Syrian Monasticism," in Vincent L. Wimbush \& Richard Valantasis (eds.), Asceticism (New York: Oxford University Press, 1995) 232). He argues that Nedungatt, in translating qyâmâ as 'covenant', "leaves unexplored the further connotations of the expression in Syriac" (230). These connotations include "the resurrection idea that is never far below the surface when the root $\mathrm{q}-\mathrm{y}-\mathrm{m}$ is employed" as well as "the fact that a number of nouns derived from this root straightforwardly bespeak one's status of station in life in the church" (231). However, in the ensuing discussion Griffith concedes that Aphrahat never explicitly makes a connection between byay/bnât qyâmâ as a phrase and resurrection, though it would be hard to deny that it remains an important background concept (since ascetics are said to have taken on the "image of angels" [6.1] and therefore anticipate the resurrection). Furthermore, Griffith's exploration of the idea of status or station in life draws exclusively from Ephraem, in contrast to Nedungatt who limited his detailed analysis to Aphrahat. In the case of Aphrahat, we are dealing with a possible connotation, not a denotation, though the distinction between these two is not always easy to determine. With respect to both of these connotations (resurrection and status) a case could be made for the logical priority of a term such as 'covenanters', since it is on the basis of their covenant of celibacy with Christ that certain people attain special status and acquire the image of angels.

4 As Edmund Beck says, "On ne trouve nulle part chez Aphraat la moindre indication que ces groupements d'ascètes se soient efforcés de manière ou d'autre de se séparer de la communauté chrétienne pour s'enfuir dans le désert ou dans les montagnes. Au contraire, l'idée de bnay qyâmâ montre précisément la connexion la plus étroite avec l'ordre sacramentel et hiérarchique" ("Ascétisme et Monachisme chez Saint Ephrem," OrSyr 3 [1958]: 277).

${ }^{5}$ See Pierre, Aphraate, $98-111$. 
indicate a fairly negative assessment of women. This, however, is not the whole picture, as these negative passages need to be seen together with other passages from Aphrahat which present a different viewpoint. From our modern perspective, there is no justification for the misogynist language and attitudes which we encounter in a writer such as Aphrahat, yet this should not prevent us from using his own words to qualify what he says and to seek to understand better his pattern of thinking by examining the larger context for his negative statements about women.

Rather than trying to summarize these statements, it will be much more effective to let Aphrahat speak for himself. In $6.2,{ }^{6}$ he lists the various ways in which "those who are spiritual" are able to resist the attacks of the Evil One, a list which ends with the mention of living alone as a response to the desire for women. ${ }^{7}$ This leads into section 3, which reads as follows: ${ }^{8}$

For it was through Eve that [the Evil One] came against Adam, and in his innocence Adam was enticed by him. He also came against Joseph, through his master's wife, but Joseph was aware of his deceptiveness and did not wish to obey him. Through a woman he fought with Samson, until he took away his naziriteship. Reuben was the firstborn among all his brothers, but through his father's wife [the Adversary] cast a blemish upon him. Aaron was high priest of Israel, but because of Miriam his sister he envied Moses. Moses was sent to deliver the people from Egypt, but he took with him a wicked counsellor; the Lord came upon Moses and wanted to kill him, until he sent back his wife to Midian. David was victorious in all his battles, but by means of a daughter of Eve a blemish was found in him. Amnon was attractive and handsome to look at, but [the Adversary] imprisoned him with a desire for his sister, and Absalom killed him because of the humiliation of Tamar. Solomon was greater than all the kings of the earth, but in his old age his wives led his heart astray. Through Jezebel,

6 The section numbers used here follow the critical edition of Aphrahat by J. Parisot, Aphraatis Sapientis Persae Demonstrationes (PS 1; Paris, 1894), entire volume; (PS 2; Paris, 1897) 1-497.

${ }^{7}$ By default, it is male asceticism that Aphrahat discusses.

${ }^{8}$ All translations are my own. 
daughter of Ethbaal, the wickedness of Ahab increased, and he became greatly defiled. [The Adversary] also tempted Job, through his children and his possessions, but when he found that he could not overpower him, he went out to get his [secret] weapon. He came back and brought with him a daughter of Eve, who caused Adam to sink, and through her mouth he said to Job, the righteous man, "Curse God!" But Job rejected her counsel. King Asa also conquered the Accursed of Life when he wanted to come against him through his mother. For Asa knew his deceit, and he removed his mother from her high position and cut the idol to pieces and threw it down. John was greater than all the prophets, but Herod killed him because of a dance of a daughter of Eve. Haman was rich, and the third in command after the king, but his wife counseled him to destroy the Jews. Zimri was the chief of the tribe of Simeon, but Cozbi, daughter of the chiefs of Midian, overthrew him, and because of one woman twenty-four thousand [men] fell in one day.

In this passage Aphrahat presents one of his many lists of scriptural exemplars, ${ }^{9}$ one which proves, to his satisfaction, that women have been the downfall of men. The examples fall into two basic categories. In some cases, men are tempted or led astray directly because of possible or actual sexual relations with a woman (Joseph, Reuben, David, Amnon, Herod (?), Zimri). In most of the other cases, men are tempted or led astray by the wicked advice of

${ }^{9}$ For a classification of such lists in Aphrahat, as well as a discussion of their possible historical background, see Robert Murray, "Some Rhetorical Patterns in Early Syriac Literature," in Robert H. Fischer (ed.), A Tribute to Arthur Vööbus (Chicago, 1977) 109-31. As Murray points out, the use of lists of exemplars is an ancient rhetorical pattern with roots in the O.T. itself. The practice can be traced throughout Jewish and Christian literature. The passage just quoted from 6.3 is classified by Murray in the category "Examples of those who were led into sin," with the added feature that Satan is named as agent. After examining three passages listing Satan's actions from other texts (Acts of Judas Thomas; Martyrdom of Cyriacus and Julitta; Commentary on Job by Julian the Arian) Murray says that the most probable original Sitz im Leben for such lists was exorcism, though of course this has nothing explicitly to do with Aphrahat's purpose in demonstration 6 . 
their wives (Adam, Samson, Aaron, Moses, Solomon, Ahab, Job, Haman); their downfall is not attributed to sexual activity per se but this fact remains in the background. ${ }^{10}$ In the remaining example, Asa's mother sought to use her status as queen mother (which is rooted in sexuality, i.e. the fact that a sexual union produced Asa) to lead him astray. Some of these men (Joseph, Job, Asa) were able to resist temptation, but most were not. In all cases (with the exception of Adam), it is female sexuality itself (either directly or indirectly) that is used to tempt men or lead them astray. It cannot be said, therefore, that women are criticized simply because they possess certain human characteristics which are more prevalent in their gender but that might occur in men also. When Aphrahat presents this list of scriptural examples, he almost certainly has in mind the dangers of associating with the 'daughters of Eve', i.e. ordinary women who have sexual relations and bear offspring. There is no doubt that men, too, can offer wicked (i.e. Satanic) counsel (see paragraph 10 below), but the effectiveness of the counsel in the examples Aphrahat gives seems predicated on the fact of a sexual relationship. It must be kept in mind, of course, that for Aphrahat the ultimate threat is the Adversary or Evil One, who chooses to attack men through women. Nevertheless, women are not cast in a very favourable light by being associated with Satan. After instructing his ascetic readers that none of them should live with the opposite sex (6.4), ${ }^{11}$ Aphrahat presents another list of exemplars in 6.5, this time in order to show that many great biblical leaders were celibate. The list includes Moses, Joshua, the priests, Elijah, Elisha, John the Baptist, and Paul and Barnabas. Aphrahat's presuppositions about (non-ascetic?) women are illustrated by the fact that these men exemplify celibacy in the service of God, yet women, he points out, were not even allowed into the tabernacle: "And the temporal tabernacle was not serviced by women, for the Law did not allow women to enter into it: even when they came to pray, they would pray at the door and turn back." It isn't clear just what part of the Law Aphrahat has in mind

${ }^{10}$ Adam represents a special case, of course, since it was thought that there were no sexual relations between the first couple until after their disobedience.

${ }^{11}$ Here he addresses women as well as men. 
(Exodus 38:8?). ${ }^{12}$ What is clear is that he mentions the absence of women in the tabernacle to prove that Joshua, who, he says, "did not depart from the tabernacle" (cf. Exodus 33:11), was celibate. Nevertheless, we are left with the impression that Aphrahat has simply reinforced the association of women with impurity and unholiness. Then, in the opening lines of 6.6, he reiterates his point that women have been used by Satan to tempt men:

On this account, brothers, we know and have seen that from the beginning women have been a way for the Adversary to gain access to men, and until the end he will [continue to] accomplish this. For [women] are the weapon of Satan, and through them he fights against the [spiritual] athletes. Through them he plays music at all times, for they have been like a harp for him from the first day. It was because of them that the curse of the Law was established, and it was because of them that the promise of death came. With pains they bring forth children and deliver [them] to death. Because of them the earth was cursed, so that it would bring forth thorns and thistles.

Here women are said to be responsible for the "curse of the Law," which, as the lines following make clear, refers to the curses recorded in Genesis 3:14-9 rather than those found in the Mosaic legislation (Deuteronomy 27:15-26 and 28:15-68). Thus, in Aphrahat's opinion, women can be blamed not merely for the downfall of various biblical heroes, but more fundamentally for allowing themselves to be used by Satan to mar God's good creation. There is no mention of the possibility that men may have had some part in creating this state of affairs. ${ }^{13}$

${ }^{12}$ Parisot hazards no guess as to which verses might be referred to here. Marie-Joseph Pierre, editor of the French edition of Aphrahat, lists only Exodus 38:8 as a possible reference (Aphraate le sage persan. Les Exposés. I. Exposés I-X [Sources chrétiennes 349; Paris: Éditions du Cerf, 1988] 377). 1 Samuel 2:22 provides the only other reference in the Hebrew Bible to the "women who served at the entrance to the tent of meeting."

13 The account in Genesis, at least, makes it clear that Adam "listened" to his wife (and thus, indirectly, to the serpent) and therefore failed, like Eve, to resist temptation. In the two passages just quoted, Aphrahat assigns men a merely passive role. 
Before considering the ways in which Aphrahat's perspective on women can be shown to be wider than what is expressed in the passages above, it will be helpful to place his comments in the context of early Christian literature. We need to keep in mind, however, that while Aphrahat was not completely isolated from the Graeco-Roman world, he was writing in the Persian empire, and his thinking was shaped by a form of Christianity that had developed differently than that of the West. ${ }^{14}$ Nevertheless, he shares his conviction that women have been used by Satan to tempt and deceive men with a wide range of early Christian texts. This conviction is usually expressed in the context of a preference for celibacy, or, in more extreme cases, a rejection of marriage. In the early Syriac milieu, the latter can be traced through the Gospel of Thomas (early to mid- $2^{\text {nd }}$ century), the Diatessaron of Tatian (late $2^{\text {nd }}$ century), and the Acts of Judas Thomas (early $3^{\text {rd }}$ century). ${ }^{15}$ However, none of these texts blames women for the ills of the world. Aphrahat himself, writing between 336 and 345 C.E., does not reject marriage, but it is clear that he holds to the ideal that true

${ }^{14}$ See for example Sebastian Brock, "Jewish Traditions in Syriac Sources," Journal of Jewrish Studies 30 (1979), and H. J. W. Drijvers, "East of Antioch: Forces and Structures in the Development of Early Syriac Theology," in East of Antioch: Studies in Early Syriac Christianity (London: Variorum, 1984) 1-27.

${ }^{15}$ In his article on the Gospel of Thomas Ron Cameron provides a good summary of the attitude toward sexuality which lies behind all three of these texts: "Becoming a solitary or single one is signified in Gos. Thom. by baptismal initiation. Sayings that focused on the disciples' stripping themselves naked, being without shame, treading on their garments, and becoming as little children (sayings $21.1-2,22,37$ ) were elaborated in baptismal practices and attendant interpretations of the Genesis accounts of the creation and the fall... According to this tradition, the unity of the first human was disrupted by the creation of woman and the subsequent sexual division. Redemption was imagined to be the replication of Adam and Eve's primordial state, the reunification of the sexes and transcendence of the world" ("Thomas, Gospel of," in David Noel Freedman [ed.], The Anchor Bible Dictionary [New York: Doubleday, 1992] VI, 539). See the article by Drijvers mentioned in the previous footnote for a discussion of all three sources. It is far from clear, in my opinion, that the Gospel of Thomas is not before Tatian, rather than after as Drijvers would have it. 
Christian living takes place in the context of celibacy. One is tempted to suppose that a trade-off has occurred: while encratism (with its androgynous ideal) has been rejected, non-ascetic women have become targets of theological abuse. There simply isn't enough evidence, however, to prove a relationship between the rejection of encratism and the growth of misogyny in early Syrian Christianity.

With reference to Greek and Latin sources, which have been studied more intensively on the topic of women, Elizabeth Clark discusses the "stereotyping, universalizing, and naturalizing of "woman" in patristic literature."16 Thus for Jerome (and many other male authors) a stereotypic trait of "woman" is weakness, or "softness of soul," while Chrysostom warns ascetic men to reject 'spiritual marriage' (i.e. ascetic cohabitation, an issue for Aphrahat also, as we shall see) so as to avoid taking on the many negative characteristics of women and to avoid being influenced by them in any way. In a similarly misogynist vein, appeals to 'nature' as a way of keeping women in their place took a variety of forms and often functioned as a legitimization of stereotypical views. Thus it was widely held that women were weak by nature, and that women were to be subordinate to men by God's design. As for the universalizing of "woman," Clark says that this was most often expressed in the "amalgamation of all women to "woman" and the identification of "woman" with Eve," supported, of course, by 1 Tim 2:11-5, with its clear subordination of women and its claim that it was Eve who sinned first. ${ }^{17}$ It is clear that Aphrahat universalizes "woman" in the passage quoted above. It is interesting

16 Elizabeth A. Clark, "Ideology, History, and the Construction of 'Woman' in Late Ancient Christianity," Journal of Early Christian Studies 2:2 (1994): 166-9. Stereotyping, universalizing, and naturalizing are three functions of ideology in general, according to the sources Clark draws on in her study (see pp. 160-1).

17 Clark (ibid., 169) quotes a well-known passage from Tertullian (early $3^{\text {rd }}$ c.) as an example of universalization: "You are the Devil's gateway; you are the unsealer of that tree; you are the first forsaker of that divine law; you are the one who persuaded him whom the Devil was not brave enough to approach; you so lightly crushed the image of God, the man Adam; because of your punishment, that is, death, even the Son of God had to die. And you think to adorn yourselves beyond your "tunics of skins." (Gen 3.21)?” 
to note, however, that though he quotes from 1 Timothy on other occasions he never makes use of 2:11-5. Furthermore, any stereotyping and naturalizing in Aphrahat takes place indirectly. He is content to list biblical examples and claim that Satan has been at work through women. The reader is left to figure out what the 'natural characteristics' of women are; unlike many Greek and Latin authors, Aphrahat himself supplies no explicit list. Despite the harsh tone of the passages quoted above, when compared to certain Greek and Latin Church Fathers, Aphrahat appears fairly moderate. ${ }^{18}$ He stays close to the biblical text and does not develop any comprehensive misogynist rhetoric.

Returning to the main thread of our discussion, if we read a little further beyond the passage from 6.6 quoted above, we begin to see one way in which Aphrahat's views on women might be qualified:

But now, by the coming of the child of the blessed Mary, the thorns are uprooted, the sweat is wiped away, the fig tree is cursed, the dust is made salty, the curse is nailed to the cross, the point of the sword is removed from before the tree of life (which is given as food to the faithful), and paradise is promised to the blessed and the virgins and the holy ones.

Here the focus is on Christ, who leads the faithful back to paradise, but Mary plays an important role as well. She functions as the antitype to Eve, since it is through her giving birth to Christ that the curse which Eve brought upon all humanity is able to be "nailed to the cross." Elsewhere in the Demonstrations there is

18 A similar point can be made about Aphrahat with reference to a recent article by Virginia Burrus ("The Heretical Woman as Symbol in Alexander, Athanasius, Epiphanius, and Jerome," Harvard Theological Review 84:3 (1991): 229-48). Burrus shows how these authors related heresy to women in general and feminized their male (heretical) opponents. For his part, Aphrahat makes no connection between women and heresy beyond the fact that the biblical record shows that women have been used by Satan to deceive men at various times. However, this should not surprise us, since he has virtually nothing to say about heretical groups (see 1.19; 3.9). The opponents that Aphrahat is concerned about are the Jews, but he never accuses them of being led astray by women, or of inflitrating the church through female 'heretics'. 
relatively little mention of Mary. She appears in yet another list of exemplars, this time to illustrate the importance of prayer and fasting, which Aphrahat takes to be the basis for Mary's finding favour with God (3.14). She also appears in a discussion of humility, which Aphrahat says both facilitated her reception/conception of Christ and brought upon her Gabriel's blessing of peace (9.5). In a list of female prophets she is called "a prophet and the mother of the Great Prophet" (14.33; I return to this passage below). In all three of these examples Mary appears simply as one example among many. There are three other passages, however, which cast further light on the role of Mary alluded to in the passage from 6.6 quoted above. In a discussion of Christ's humility, which leads him to leave his divine "natural condition" and enter into the "natural condition" of human beings, Aphrahat describes the relationship between Christ and believers in terms of an exchange of pledges. When Christ ascended to heaven, he took with him a pledge from humanity: the human body in which he was incarnated. And when he arrived at the Father's right hand, says Aphrahat, he sent a pledge of his own: his Spirit, which is present in all believers. It is in this context that Mary is mentioned in passing:

When he came to us, he did not possess anything that was ours, nor did we possess anything that was his: the two natures were his and his Father's. For when Gabriel announced his birth to Mary the blessed one, the Word proceeded from on high and came, and the Word became a body and lived among us. And when he returned to the one who sent him, that which he had not brought set out and went [also], as the apostle said, "He raised us up and seated us with him in heaven."19 And when he went to his Father he sent us his Spirit and said to us, "I am with you until the end of the world." 20 (6.10)

Two further passages from the very last of the demonstrations fill out Aphrahat's account of the role of Mary in salvation history:

Jesus was born from Mary the virgin, from the seed of the house of David and from the Spirit of holiness, as it

\footnotetext{
19 Ephesians 2:6.
}

${ }^{20}$ Matthew 28:20. 
is written, "Both Joseph and Mary his betrothed were from the house of David." 21 And the apostle testifies, "Jesus Christ, from Mary, was from the seed of the house of David through the Spirit of holiness."22 Joseph was called the father of Jesus (even though he was not born from his seed), but the name of fatherhood was transmitted from Adam to Joseph, through sixty-three generations. But the name of fatherhood was lifted from Joseph and placed on Christ. From Joseph he received the name of fatherhood, from John [he received] the name of the priesthood, and from Mary he put on a body and received the name of birth. (23.20)

How great is the gift of goodness which is with us! The King took from us a pledge which is like him; the Lover has made it and will guard it to the end. This is a son of Adam, a body which came from Mary, who was led from us to the country of life. The weak body became strong, and received a glory which was greater and more wondrous than that which Adam stripped off in his fall. ${ }^{23}(23.51)$

Here the role of Mary is said to have been the 'embodying' of Christ; the pledge that he took with him was a gift from Mary, acting, one might say (though Aphrahat himself does not say this explicitly), as a representative of all humanity. The role of Mary, then, is extremely significant: without her, God's Spirit, the pledge of Christ, would not have been given to humanity. And here, in Aphrahat's last known writing, we encounter the idea that it was Adam who, in his fall through weakness, caused the glory of creation to fade, an idea which we might wish had found expression in the passages critical of women quoted above. ${ }^{24}$

${ }^{21}$ Luke 2:4-5.

22 Romans 1:3-4.

23 The term translated "fall" (shaplutâ) is used only two other times in Aphrahat, in both cases meaning simply 'weakness' (see 7.4; 14.43). Here that meaning could be used as well, thought "fall" fits in better with the idea of a definitive loss of glory.

${ }^{24}$ Adam's weakness is also emphasized (with no mention of Eve) in the opening sentence of 23.3: "It was because the first man gave his obedience to the serpent that he received as punishment the curse that he would become the nourishment of the serpent, and the curse has been 
Nevertheless, it is clear that an examination of the role of Mary in Aphrahat's account of salvation history provides a counterpoint to those passages. She plays a significant role in reversing the effects of the disastrous decision made by Eve. ${ }^{25}$

If we continue our reading of 6.6 we encounter another passage which serves, to a certain extent, to weaken the impact of Aphrahat's demonization of women. A discussion of the significance of the coming and the death of Christ (cf. the passage quoted at the beginning of 3] above) subtly shifts to a discussion of the wedding feast of the heavenly Bridegroom. The eschatological orientation of Aphrahat's asceticism becomes clear:

Those who return to sheol weep and gnash their teeth, but those who enter the kingdom are glad and rejoice and dance and sing praises. For those who do not take wives are ministered to by the watchers of heaven.

transmitted to all his offspring." Aphrahat then proceeds to a very interesting discussion of the tree of life.

${ }^{25}$ Averil Cameron argues that the development of a cult of the Virgin was related to the development of Christology: "Virginity stood for the paradoxes at the heart of Christianity. It is this very paradoxical qualitythe notion that only through virginity, that is, by denying nature, can true virtue be attained - that gave the theme a centrality over and above mere misogyny... Mary was the prime example. The virginity of Mary, already a theme at the end of the second century AD for Tertullian (one of the foremost of Christian misogynist writers), and the subject of narratives supplementary to the laconic statements about her in the Gospels, became in the late fourth and early fifth centuries, when preoccupations with Christology and with the theme of virginity in general were both at their height, one of the central topics in the rhetoric of the Church... The Virgin of late antiquity was... a rhetorical construction formed from the need to weave together contemporary attitudes to women and sexuality and the logical implications of the doctrine of the incarnation" "Virginity as Metaphor: women and the rhetoric of early Christianity," in History as text: the writing of ancient history [Chapel Hill: University of North Carolina Press, 1990] 190). Once again Aphrahat represents a contrast. The debates of the Council of Nicaea have left no impact on his writings, and the virginity of Mary is not made a subject of theological discussion. The role of Mary is not to preserve the purity of Christ so much as to provide him with a body which can then be taken up into heaven in the great drama of salvation. 
Those who have guarded holiness rest in the sanctuary of the Most High. The Only-Begotten who is from the bosom of his Father makes all the single ones rejoice. In that place there is neither male nor female, neither slave nor free person, but all are children of the Most High. ${ }^{26}$ All the pure virgins, those who are betrothed to Christ, light their lamps in that place and go with the Bridegroom into the bridal chamber. ${ }^{27}$ All those who are betrothed to Christ are far removed from the curses of the Law, and are saved from the penalty imposed on the daughters of Eve, for they do not unite with men, and [therefore do not] receive the curses and do not experience the pains [of childbirth]. They do not consider death, since they do not hand children over to it, and in place of a mortal husband they are betrothed to Christ... Instead of the groans of the daughters of Eve they utter the songs of the Bridegroom. The wedding feast of the daughters of Eve is for seven days, but [the pure virgins] have a Bridegroom who never goes away. The adornment of the daughters of Eve is wool which wears out and is destroyed, but [the pure virgins] have garments which do not wear out. Old age withers the beauty of the daughters of Eve, but the beauty that [the pure virgins] have is renewed at the time of the resurrection.

In this passage there is only one line about ascetic men, whose reward is to be "ministered to by the watchers of heaven." Most of the passage has to do with ascetic women, who are contrasted with the "daughters of Eve." The phrase "daughters of Eve" functions as a designation for women in general, who marry and have children, and are burdened with thoughts of death and the loss of their physical beauty. It should be noted that the entrance of the pure virgins into the bridal chamber of the heavenly Bridegroom provides a contrast with Aphrahat's earlier comment that the Law forbade women entrance into the earthly sanctuary. It should also be noted, however, that, according to Aphrahat, "those who enter the kingdom" are "neither male nor female... but all are children of the Most High." One could say that female covenanters are no longer 'women' in the ordinary sense of the word, and therefore

\footnotetext{
${ }^{26}$ Luke 6:35; Galatians 3:28.
}

${ }^{27}$ Matthew 25:7-10. 
avoid the possibility of becoming instruments of Satan. Thus the eschatological context for Aphrahat's asceticism both corroborates his negative statements about women and points to a final blessed state in which women are invited to participate. ${ }^{28}$

Another counterpoint to Aphrahat's negative view of women as expressed in 6.3 and 6.6 is provided by the language with which he describes various groups of men, in particular the male leaders of his own church. It turns out that women are not alone in being labelled as instruments of Satan by Aphrahat. He also refers to the followers of Marcion, Valentinus, and Mani, as well as the "school of Babylon," as "deceptive schools" which are "instruments of the Evil One" (3.9). The two other references to "empty" or "deceitful" teachings as being instruments of the Evil One (1.19; 6.18) almost certainly refer to these same groups. These heretics are demonized on the basis of their defective doctrine. In the case of the leaders of the church, however, it is not doctrine so much as behaviour that is at issue. Aphrahat's objection to their behaviour (and in particular to the behaviour of the bishop of SeleuciaCtesiphon) is found, appropriately enough, in demonstration 14 ("An Exhortation"). His denunciation of these leaders is most evident in 14.37, a long section in which nothing, apparently, is held back. Here is but a short sample of Aphrahat's strident criticism:

Because of a stirring up of confusion and controversy, headstrong and wicked men have spread among our people. [These men are] ambitious and scornful, foulmouthed and cursing, jealous and spiteful, agitators and lovers of greed. They rejoice in destruction and delight in slippery places. They hate truth and drive away righteousness. They pillage, defraud, deceive, and pour contempt on their friends. They are established in falsehood, and concealed in wickedness... They eat in the name of our Lord and are honoured in his name and proclaim in his name, but they are empty of his words. These people are deceitful labourers who hold on to money and make no profit. They are wicked servants who oppress their fellow servants. They are

28 We don't know what Aphrahat's opinion of married Christian women was. His audience consisted of male and female ascetics, and he says very little directly about the lay state. 
darkness within light, false prophets and deceptive messiahs. They are evildoers, ${ }^{29}$ inheriting darkness, who ask for water from the righteous. ${ }^{30}$ They are thorns in the vineyard; they build on sand a structure that falls. ${ }^{31}$ They turn away from the battle, for their god is their stomach and their glory their shame. ${ }^{32}$ They are whitewashed walls, ${ }^{33}$ the army of the Evil One, the offspring of Satan... They are the poison of death, the venom of the serpent, the tooth of the viper. They are adversaries of the cross, the stumbling block of the crucifixion, the enemies of Christ.

Clearly, in Aphrahat's opinion, the leaders of the Persian Church are quite the opposite of what they are supposed to be! They are not merely falling short in their duties. Rather, they are actively supporting the cause of Satan, according to Aphrahat. If we compare the language used to describe these leaders with the language used to describe women in 6.3 and 6.6 , it becomes clear that the former are more thoroughly demonized than the latter. Perhaps this is because the context of the discussion is different in each case. In demonstration six, Aphrahat's attention is focussed for the most part on the proper behaviour of male covenanters. ${ }^{34}$ It is only natural that women would be perceived as a threat to this particular subset of the church. However, in the case of the church leadership, it is not simply the ascetic subset that is being affected by Satanic influence, but the whole church. Perhaps this is why Aphrahat makes use of stronger language in his denunciation of immoral leaders than he does in his denunciation of women in general. This is another way of suggesting that Aphrahat is not merely concerned with the ascetic wing of his church, but with the

${ }^{29}$ Literally, 'children of the left'. As the second part of the verse makes clear, the reference is to those on the left of Christ at the final judgement (see Matthew 25).

${ }^{30}$ See Luke 16:24 (Lazarus and the rich man).

${ }^{31}$ See Matthew 7:26; Luke 6:49.

32 Phillipians 3:19.

${ }^{33}$ Cf. Acts 23:3.

34 Though he offers instruction to female covenanters directly (6.7), his 'default mode' is male asceticism, as seen by the use of the term "man" (rather than the generic "person") in the opening lines of 6.8, where he outlines the behaviour appropriate for (male) covenanters. 
health of the church as a whole. This is, of course, speculation on my part. It is clear, however, that women are not the only group that is demonized in Aphrahat. Both heretics and corrupt church leaders receive similar (and in the case of the latter, more severe) treatment. Granted, women are demonized because of their sex, while men are demonized on account of their behaviour, not because they are males. Nevertheless, if women were the only locus of Satanic activity mentioned by Aphrahat, his estimation of women in general could be said to be even lower than it actually is. The idea that men, too, are quite capable of being used by Satan introduces some balance into the picture, whether this was what Aphrahat intended or not. ${ }^{35}$

The most effective counterpoint to Aphrahat's negative statements about women are certain passages containing unambiguously positive statements about women. Consider the following lines from 14.11:

Take note, my friends, that at certain times and in certain generations God has given great victories through wise people, that they might reconcile and bring peace to divisions, and this not through men only, but also through women. Through the instruction of Joab, the woman of Tekoa reconciled Absolam with David. ${ }^{36}$ And by means of a woman peace came to Israel when Shamu son of Bakri rebelled against David. A wise woman spoke from the wall with Joab and said, “'Listen Joab, listen!' And he said, 'I am listening.' She said to Joab, 'They used to say in former days, 'They inquired of the prophets, and then they brought and end [to a matter].' Am I the one to pay Israel's penalty? You are seeking to destroy a handmaiden and a mother of Israel.' Joab said to her, 'Far be it from me! I will not destroy or ruin; this is not the way things are. But there

35 In this connection it is interesting to note that when Aphrahat counsels female ascetics in 6.7 not to give into the requests of male ascetics who (ostensibly) want someone to live with them and "serve" them, it is in fact the male who is playing the satanic role of tempter. Cf. also 14.40 , which lists O.T. figures who have been enticed by Satan by "cravings of various kinds," adding Judas and Israel in general at the end. Only two of the 33 entries are women: Potiphar's wife and Delilah. The rest consist of men who have been unwitting instruments of Satan.

362 Samuel 14:1-24. 
is a man, Shamu son of Bakri, who has raised his hand against King David. Give him to us and he will go with us.' And she said to him, 'Soon his head will be thrown to you from the wall.' She went and spoke with all the people, and she cut off the head of Shamu son of Bakri and threw it from the wall to Joab." 37 Thus peace came to Israel through a woman. Deborah was a mother who administered justice in Israel. And Jael, the wife of Heber the Kenite, cut off and cast away the glory of Sisera, the leader of the army of Jabir, king of Hazor, when she drove a stake into the temple of his head... And Rebecca, the mother of the righteous, established peace between Esau and Jacob when she sent Jacob to be with Laban. Our Saviour, the great king who has reconciled a rebellious world to his Father, while we were wrong-doers carried the transgression of all of us and became an ambassador of reconciliation between God and his creation.

There are (at least) three striking features of this passage. First, it follows section 10, which is a list of biblical men whose pride has been their downfall. The virtue of these women is set in sharp relief. Second, there is no comparable list of wise men who have been used by God to bring victory for his people. Such lists occur elsewhere in the Demonstrations but nowhere in the vicinity of this passage. And third, this list of women ends, as if there were no discontinuity, with Christ himself, who is the ultimate "ambassador of reconciliation." The implication is clear: Aphrahat is arguing that there have been many Christ-like women in biblical history. Another passage I have already had occasion to mention: Mary the mother of Jesus is included in a list of female prophets in 14.33. In 14.32, Aphrahat laments the troubles afflicting the Persian church, including the misuse of power and the stirring up of controversy. It is in such a context that "the strong are tested," those who "stand in the gap and repair the wall" on behalf of their people. This leads to the discussion in section 33, the theme of which is God's elevation of the humble over the proud and mighty. After a long list of men who illustrate his point, he adds a list of women:

It has been the same with women: he elevated Sarah over Hagar, the mother of [Abraham's] firstborn;

372 Samuel 20:16-22. 


\begin{abstract}
Rachel over Leah; Hannah over Peninnah; Esther over Vashti. Furthermore, prophecy and judgement were accomplished by women at certain times, since this pleased the one who elevates the humble. Miriam was a prophet; Hannah was a prophet; Huldah was a prophet; Elizabeth was a prophet; Mary was a prophet and the mother of the Great Prophet; Deborah was a prophet and a judge of Israel in the days of Barak, son of Abinoam, the king. No one can find fault with the will of our good God, for no one has searched out his judgements. His ways cannot be analyzed, his judgements cannot be comprehended, and his mind cannot be measured.
\end{abstract}

I cannot refrain from speculating that Aphrahat had some reason for making these points about biblical women. It seems that he is providing the reader with a kind of subtle self-correction of his earlier statements in 6.3 and 6.6. Or, at least, he seems to want to balance the harsh tone of those statements. We know that demonstration 14 was 'published' about eight years after demonstration 6. Even if it was actually written some time before it was published, there was probably a span of several years between the composition of the two demonstrations, especially since the sixth, too, may have been written some time before it was published. Perhaps something happened in that time that motivated Aphrahat to make a clear statement of the positive role of women. Given the fact that the biblical examples he refers to have to do with prophecy and reconciliation, it is possible that certain women were performing those roles in Aphrahat's community in a way that caught his attention in the time period between the writing of the two demonstrations. On the other hand, it may be that Aphrahat was not providing self-correction by an emphasis on women's roles in his later writings. He may not have sensed any contradiction at all between his harsh language in demonstration six and his two lists of biblical women in demonstration fourteen. Just as he occasionally addressed female ascetics in demonstration six, so here too he may simply be recognizing that not all women are instruments of Satan. We cannot be sure that Aphrahat would make a connection between the prominence of women's roles and their asceticism, but this seems likely, despite the fact that most biblical women are clearly married. If this is so, then, as I pointed out earlier (see the end of 
paragraph 4), an emphasis on the importance of women's roles is the corollory to Aphrahat's denigration of women in general, since ascetic women have ceased to be women in the ordinary sense of the term. Once again we are hindered by our lack of knowledge of Aphrahat's opinions about non-ascetic Christian women.

I began this brief study by saying that Aphrahat's writing reflects "misogynist language and attitudes." Was this a fair assessment? I think it was, insofar as using language that demonizes women and blames them for the ills of the world is, from a modern point of view, profoundly counterproductive, even for male ascetics who experience women as objects of misplaced desire. ${ }^{38}$ However, what I hope to have shown here is that when the Demonstrations are read in their entirety, it becomes possible to qualify (but not neutralize) Aphrahat's extreme statements with the recognition that i) Mary's role in salvation history is clearly, if briefly, emphasized; ii) the distinctions between male and female disappear at the resurrection; iii) women are by no means the only group that is demonized; and most importantly, iv) Aphrahat himself makes unambiguous statements about the value of women in God's work of reconciliation. As I made clear at the start of this study, I am not of the opinion that any of this is able to prevent a modern reader of Aphrahat from coming to the conclusion that he perpetuated misogynist attitudes. If the modern reader of the Demonstrations, however, objects to the author's misogyny, it may be that Aphrahat, in turn, might have a few things to say about certain of the reader's attitudes which could prove quite challenging. My purpose will have been fulfilled if I have been able to contribute to an understanding of the wider context within which these attitudes are expressed. It has become clear that even after we have gained some understanding of the larger context provided by the Demonstrations, a certain ambiguity remains with respect to Aphrahat's attitude toward women. On the one hand, women represent a threat to the male ascetic's dedication to Christ. On the other hand, Mary and other biblical women show the importance

38 This is not to deny that such language may have served an important function in the male ascetic community in antiquity. We can hardly refrain from concluding, however, that an asceticism which demonizes either sex is in that respect at least immature, despite its many other strengths. 
of the female sex to the history of salvation. Though Aphrahat shares his ambiguous attitude toward women with many Greek and Latin sources, I have argued that he represents a more moderate position than that usually found in the West.

\section{BIBLIOGRAPHY}

Beck, E. “Ascetisme et Monachisme chez Saint Ephrem.” SyrOr 3 (1958): 273-98.

Brock, Sebastian. "Jewish Traditions in Syriac Sources." Journal of Jewish Studies 30 (1979): 212-32.

Burrus, Virginia. "The Heretical Woman as Symbol in Alexander, Athanasius, Epiphanius, and Jerome." Harvard Theological Review 84:3 (1991): 229-48.

Cameron, Averil. "Virginity as Metaphor: women and the rhetoric of early Christianity." In History as text: the writing of ancient history, 181205. Chapel Hill: University of North Carolina Press, 1990.

Cameron, Ron. "Thomas, Gospel of.” In Freedman, David Noel, ed. The Anchor Bible Dictionary, VI, 535-40. New York: Doubleday, 1992.

Clark, Elizabeth A. 'Ideology, History, and the Construction of 'Woman' in Late Ancient Christianity." Journal of Early Christian Studies 2:2 (1994): 155-84.

Drijvers, H.J.W. "East of Antioch: Forces and Structures in the Development of Early Syriac Theology." In East of Antioch: Studies in Early Syriac Christianity, 1-27. London: Variorum, 1984.

Griffith, Sidney H. "Asceticism in the Church of Syria: The Hermeneutics of Early Syrian Monasticism." In Wimbush, Vincent L., and Richard Valantasis, eds. Asceticism, 220-45. New York: Oxford University Press, 1995.

Murray, R. "Some Rhetorical Patterns in Early Syriac Literature." In Fischer, Robert, ed. A Tribute to Artbur Vööbus, 109-31. Chicago: Lutheran School of Theology, 1977.

- "The Characteristics of the Earliest Syriac Christianity." In Garsoian, Nina G., Thomas P. Mathews and Robert W. Thomson, eds. East of Byzantium: Syria and Armenia in the Formative Period, 3-16. Washington D.C.: Dumbarton Oaks, 1982.

Nedungatt, George. "The Covenanters of the Early Syriac-Speaking Church.” OCP 39 (1973): 191-215 and 419-44.

Parisot, J. Aphraatis Sapientis Persae Demonstrationes. PS, 1. Paris, 1894 (entire volume); PS, 2. Paris, 1897, 1-497.

Pierre, Marie-Joseph. Aphraate le sage persan. Les Exposés. I, Exposés I-X. Sources chrétiennes, 349. Paris: Éditions du Cerf, 1988; II, Exposés XI-XXIII. Sources chrétiennes, 359. Paris: Éditions du Cerf, 1989. 
